\title{
The British Army's Training in International Humanitarian Law
}

Elizabeth Stubbins Bates*

\begin{abstract}
States must disseminate international humanitarian law (IHL) and integrate it into military instruction. Implementation of the IHL training obligation was delayed in the UK; when the government asserted that IHL was inapplicable to colonial warfare, resisted the development of the IHL of non-international armed conflict, and was keen to maintain the nuclear deterrent. Absent or perfunctory IHL training correlated with recurrent violations of the prohibitions of torture and inhuman treatment, from the 1950s to the 2000s. Despite official assertions that the British Army's training in IHL was being reformed following the death of Baha Mousa in British military custody in 2003, there were gradual changes from 2004-2011, and more thorough improvements from 2012-2017. Training materials for soldiers and officers now offer breadth and detail on IHL, with elements of international human rights law. They implement the 71 recommendations in the Baha Mousa Public Inquiry Report which the Ministry of Defence accepted, and are supplemented by practical training. Yet these are reactive reforms, which still lack norm-by-norm evaluation of soldiers' understanding. Prohibitions on humiliating or degrading treatment of a sexual nature, and on the intentional infliction of severe mental pain and suffering are (respectively) under-emphasised and absent. References to the necessity of restraint positions (as opposed to the prohibited stress positions) may cause confusion. There is a simplistic suggestion that reprisals are lawful if they are politically authorised. Training reforms have been cited as one reason to close criminal investigations into alleged war crimes: a response which neglects coexistent investigatory obligations.
\end{abstract}




\section{Introduction}

States must disseminate international humanitarian law (IHL) 'as widely as possible', 'including to the civilian population', and integrate it into programmes of military instruction, ${ }^{1}$ or training. ${ }^{2}$ The dissemination and training obligation applies in peace and war, unusual for IHL which generally applies only during armed conflict or belligerent occupation. The obligation to train troops in 'the text' of the Four Geneva Conventions includes the dissemination of Common Article 3 , so the IHL of non-international armed conflict (NIAC) is part of the training obligation. ${ }^{3} \mathrm{An}$ obligation to disseminate IHL appears in NIAC regulated by Additional Protocol II (AP II), ${ }^{4}$ so that armed groups are also obliged to disseminate IHL once a NIAC begins. AP II's reference only to dissemination and not to military instruction was a hurried diplomatic compromise to agree the text of the Protocol: it wasted lengthy, substantive diplomatic debate on military instruction in NIAC, and does not suggest delegates intended expressly to restrict the obligation to that of dissemination instead of military instruction. ${ }^{5}$ Amended Protocol II to the Convention on Certain Conventional Weapons includes an IHL training obligation, as does the Second Protocol to the Hague Convention on Cultural Property, both of which clarify that their 'parent' Convention' and

\footnotetext{
${ }^{1}$ Geneva Convention for the Amelioration of the Condition of the Wounded and Sick in Armed Forces in the Field of 12 August 1949, 75 UNTS 31 (entered into force 21 October 1950) (GC I) art 47; Geneva Convention for the Amelioration of the Condition of Wounded, Sick and Shipwrecked Members of Armed Forces at Sea of 12 August 1949, 75 UNTS 85 (entered into force 21 October 1950) (GC II) art 48; Geneva Convention Relative to the Treatment of Prisoners of War of 12 August 1949, 75 UNTS 135 (entered into force 21 October 1950) (GC III) art 127; Geneva Convention Relative to the Protection of Civilian Persons in Time of War of 12 August 1949, 75 UNTS 287 (entered into force 21 October 1950) (GC IV) art 144; Convention on Prohibitions or Restrictions on the Use of Certain Conventional Weapons which may be deemed to be Excessively Injurious or to have Indiscriminate Effects (adopted 10 October 1980, entered into force 2 December 1983) 1342 UNTS 137 (CCW) art 6; Jean-Marie Henckaerts and Louise Doswald-Beck, Customary International Humanitarian Law (ICRC, Cambridge University Press 2005) (ICRC Customary IHL Study), rules 142-143.

${ }^{2}$ Hague Convention for the Protection of Cultural Property in the event of Armed Conflict (adopted 14 May 1954, entered into force 7 August 1956, HCCP) 249 UNTS 240 art 25; Second Protocol to the HCCP (adopted 26 March 1999, entered into force 9 March 2004) 2253 UNTS 212 art 30.

${ }^{3}$ Iris Muller, 'Article 47: Dissemination of the Convention', ICRC Commentary of 2016: First Geneva Convention 1949 (ICRC 2016).

${ }^{4}$ Protocol Additional to the Geneva Conventions of 12 August 1949, and Relating to the Protection of Victims of Non-International Armed Conflicts (adopted 8 June 1977, entered into force 7 December 1978) 1125 UNTS 609. (AP II), art 19; Yves Sandoz, Christopher Swinarski and Bruno Zimmermann (eds), Commentary on the Additional Protocols of 8 June 1977 to the Geneva Conventions of 12 August 1949 (ICRC 1987) 1489, para 4912; ICRC Customary IHL Study, rule 142; Second Protocol to the HCCP 1999 art. 30.

${ }^{5}$ Elizabeth Stubbins Bates, 'Solving the Conundrum between Military Training, Prevention and Compliance in International Humanitarian Law' (PhD thesis, SOAS, University of London, 2017) 78; Elizabeth Stubbins Bates, 'Towards Effective Military Training in International Humanitarian Law' (2014) 96 International Review of the Red Cross 795, 800-801.
} 
Protocols apply to international armed conflicts (IAC) and NIAC. ${ }^{6}$ Where Additional Protocol I (AP I) is ratified, dissemination should encompass both military and civilian authorities, so that all of those with responsibility for applying IHL are 'fully acquainted' with the text of the Four Geneva Conventions and AP I. ${ }^{7}$ Article 82 AP I requires states parties to make legal advisers available to commanders, to advise on the application of the Geneva Conventions and Additional Protocol I, and on 'appropriate instruction' to troops in IHL. Research on this obligation therefore offers valuable insights into states' long-term implementation of IHL, and the priority (or otherwise) they give to IHL before, during and after armed conflict.

Despite this, the IHL training obligation is briefly expressed in treaty texts, leaving broad discretion to states. It is, in the words of a recent commentary, a 'due diligence' obligation, 'not one of result. ${ }^{8}$ This is not an asset. It reflects unexamined historic assertions that dissemination and training in IHL would prevent violations $;{ }^{9}$ without careful examination of training's necessity and/or sufficiency to do so, and of how IHL training programmes might be designed to improve states' compliance with IHL. ${ }^{10}$ Combined with the absence of transparent monitoring of state practice in IHL, ${ }^{11}$ the extent of states' compliance with their dissemination and military instruction obligations is lost to scrutiny. A partial counterpoint to this can be found in the Pledges by states and regional organisations on IHL dissemination and military instruction, submitted to the $32^{\text {nd }}$ and $33^{\text {rd }}$ International Conferences of the Red Cross and Red Crescent. ${ }^{12}$

\footnotetext{
${ }^{6}$ Protocol on Prohibitions or Restrictions on the Use of Mines, Booby-Traps and Other Devices as amended on 3 May 1996 (Protocol II to the 1980 CCW Convention) (entered into force 3 December 1998) UNTS 1342 art 14(3); Second Protocol to the HCCP, art 30.

${ }^{7}$ Protocol Additional to the Geneva Conventions of 12 August 1949, and Relating to the Protection of Victims of International Armed Conflicts (adopted 8 June 1977, entered into force 7 December 1978) 1125 UNTS 3 (API) art 83(2); ICRC Customary IHL Study, rule 143.

${ }^{8}$ Elzbieta Mikos-Skuza, 'Dissemination of the Conventions, Including in Time of Armed Conflict' in Andrew Clapham, Paola Gaeta and Marco Sassòli (eds), The 1949 Geneva Conventions: A Commentary (Oxford University Press 2015) 597, 612.

${ }^{9}$ Gustave Moynier, 'Si l'on veut que la Convention soit efficace, il faut en faire pénétrer l'esprit dans les moeurs des militaires et dans celles des populations tout entières. Il faut en vulgariser les principes par une propagande active.' Second International Conference of the Red Cross, Berlin, 1869, Compte-rendu des travaux de la Conférence internationale tenue à Berlin du 22 au 27 avril 1869 par les délégués des gouvernements signataires de la Convention de Genève et des sociétés et associations de secours aux militaires blessés et malades (J.F. Starcke 1869) 74.

10 Stubbins Bates, (2014) 96 IRRC 795.

11 Jelena Pejic, 'Strengthening Compliance with IHL: The ICRC-Swiss Initiative' (2016) 98 IRRC 315; Giulio Bartolini, 'Strengthening Compliance with International Humanitarian Law: The Failed Proposal for a Meeting of States on International Humanitarian Law' (2016) 25 The Italian Yearbook of International Law 201; ICRC and Swiss Federal Department of Foreign Affairs, 'Factual Report on the Proceedings of the Intergovernmental Process on Strengthening Respect for IHL' (2019).

12 Pledges on IHL Dissemination or Training from Austria, Canada, Denmark, France, Japan, New Zealand, Norway, Spain, the EU and NATO (32nd International Conference of the Red Cross and the Red Crescent,
} 
In international human rights law (IHRL), military law enforcement personnel who might have responsibilities 'for custody, interrogation or treatment of any individual subjected to any form of arrest, detention or imprisonment', must receive 'education and information regarding the prohibition against torture'; and their 'rules and instructions' must reflect this prohibition. ${ }^{13}$ The Convention on Enforced Disappearances has a similar training obligation, ${ }^{14}$ but as the United Kingdom has neither signed nor ratified this Convention, it will not be discussed further here.

This article explores the British Army's training in IHL; a case study chosen because of the deficits in military training found by the Baha Mousa Public Inquiry (into the death of an Iraqi civilian in British military custody in 2003), ${ }^{15}$ and because of the UK Ministry of Defence's frequent assertions that the recommended reforms to training had been swiftly implemented. ${ }^{16}$ Its findings resonate beyond recent history. In section 2 below, I present archival research which shows three possible reasons for the delayed implementation of the IHL training obligation in the UK. From the 1950s until the 1990s, the UK was keen a) to argue that IHL was inapplicable to colonial warfare and b) to resist the development of the IHL of non-international armed conflict, during the conflicts in Malaya, Kenya, Aden, Cyprus and Northern Ireland. There is some evidence too that c) training troops in IHL was thought to risk the legitimacy of the nuclear deterrent. Absent or perfunctory IHL training correlated with recurrent violations of the prohibitions on torture and inhuman or cruel treatment, but this correlation is more pronounced in NIAC than IAC, especially in colonial/counterinsurgency conflicts.

Following the Baha Mousa Public Inquiry, and other findings about the deficient IHL training received by troops deployed in Operation Telic, ${ }^{17}$ the government sought quickly to assert that the training had been reformed and was now sufficient. My research suggests reactive and gradual

\footnotetext{
December 2015). Pledges on IHL Dissemination or Training from Australia, Austria, Belgium, Canada, Czech Republic, Denmark, the EU and its member states, Finland, Georgia, Germany, Japan, Poland, Portugal, Spain, and the UK ( $33^{\text {rd }}$ International Conference, December 2019).

${ }^{13}$ Convention against Torture and Other Cruel, Inhuman or Degrading Treatment or Punishment 10 December 1984 (entered into force 26 June 1987) 1465 UNTS 85 (CAT) art 10.

${ }^{14}$ International Convention for the Protection of All Persons from Enforced Disappearance (adopted 20 Dec 2006, entered into force 23 Dec 2010, UNTS 2716) (CED) art 23.

${ }^{15}$ Sir William Gage, 'The Baha Mousa Public Inquiry Report' (2011) Part VI; Part XVIII, paras 292, 302, 305, 310, 318.

${ }^{16} R$ (Ali Zaki Mousa and Others) v Secretary of State for Defence [2013] EWHC 1412 (Admin) para 208; HC 27 March 2014, col32WS; Ben Sanders, Jeremy Johnson QC and Melanie Cumberland (2014) The Al-Sweady Inquiry: Closing Submissions on Behalf of the Ministry of Defence, para 1096.

${ }^{17}$ Sir Robert Aitken, 'The Aitken Report: An Investigation into Cases of Deliberate Abuse and Unlawful Killing in Iraq' (British Army 2008); Gage (n 15).
} 
improvements to IHL from 2004-2011, followed by a comprehensive approach from 2012-2017. In section 3 below, I analyse current UK state practice in the training of civilian authorities and land forces in IHL and the IHRL applicable during armed conflict, with a close reading of the Operational Law Training Directive 2014, and the instructors' notes, audio-visual materials and past papers for the Military Annual Training Test (MATT) 7 on the Law of Armed Conflict (all obtained by Freedom of Information (FOI) requests). I find that training materials for soldiers and officers are now ambitious in their coverage of IHL norms and now includes relevant IHRL on the use of force, the protection of captured persons (CPERS in the British Army acronym).

There are shortcomings (section 4). While the training materials are detailed and far-reaching, they are not systematically evaluated. ${ }^{18}$ There is no norm-by-norm data collection on whether particular IHL obligations are misunderstood. The reforms were reactive, with improvements driven by the particular questions and findings of the Baha Mousa Public Inquiry Report. A proactive approach might have analysed the full range of alleged ill-treatment in British military custody, and ensured that prohibitions on sexual assaults and other outrages upon personal dignity were more prominently included in training materials, and long before 2017. The continued permissibility of 'restraint positions' in the current training materials may cause confusion. The text on reprisals simplifies the UK's reservation to Articles 51-55 AP I and does not reflect customary IHL. Responses to FOI requests in 2018 and 2019 suggest that there have been no structural or substantive changes since the issue 9 of MATT $72017 .{ }^{19}$ The 2017 instructors' notes do not reflect the UK's ratification (also in 2017) of the HCCP and its Protocols. Finally, I find that the government cited its training 'reforms' as one argument in favour of closing investigations into alleged unlawful killings and torture or ill-treatment in Iraq. The obligation to instruct the military in IHL exists alongside the obligations to prosecute or extradite grave breaches or IHL in IAC, and obligations to 'repress' or 'suppress' other violations. Investigatory obligations persist in IHRL. Section 5 concludes: noting the delay in the UK's implementation of the IHL training obligation, the patterns of violation from the 1950s-2000s and the patterns of assertion that IHL training (or its reform) was sufficient to prevent future IHL violations. This article offers nuance and detail as a counterpoint to these assertions.

\footnotetext{
${ }^{18}$ CAT, Concluding Observations on the UK's 6th periodic report, May 2019, para 27c).

${ }^{19}$ Army Legal Services, email on file with the author, 25 March 2019.
} 


\section{Chronology}

\section{A. History of the British Army's Training in International Humanitarian Law}

Britain's 1914 Military Manual reflects contemporaneous assumptions about the causes of law of war violations and implicitly, the potential of dissemination. The Manual asserts that violations are 'almost invariably' the result of 'ignorance or excess of zeal', and that deliberate violations occur 'increasingly rarely'. ${ }^{20}$ As Hull discovered, Britain had begun to incorporate Geneva and Hague law into its field manual as early as 1904, and the 1914 Manual included 'ready-made forms, and detailed instructions clearly designed for ... use in the field. ${ }^{21}$ This is merely tentative evidence of dissemination, however; insufficient to prove that Britain had taken the 'necessary steps' to instruct its troops in the text of the 1906 Geneva Convention. ${ }^{22}$ The 1914 Manual reflected Hague and Geneva law in some detail, plus prohibitions on asphyxiating gases, bombardment, and the St Petersburg Declaration 1868 on explosive projectiles.

Reflecting other states' practice, British military doctrine permitted reprisals and collective punishment of civilians (the destruction of civilian homes) with some limitations; but urged against hostage-taking and the killing of hostages. ${ }^{23}$ Superior orders were a defence to war crimes in the 1914 Manual, until an 1944 amendment (where soldiers were expected to question and if necessary to disobey 'obviously illegal' orders) and the subsequent 1958 edition, which reiterated this. ${ }^{24}$ Bennett found that soldiers deployed to the Korean War in 1951 were reminded that they were bound by international and domestic law (suggesting a limited or perfunctory instruction for an IAC), but that the chain of command 'neglected to disseminate to either officers or men the duty to refuse illegal orders.' 25

Questions remain about the depth of and reflection about the purposes of law of armed conflict training in the early 1950s. Although the archival evidence is patchy, it seems that IHL training

\footnotetext{
${ }^{20}$ War Office, Manual of Military Law (1914, henceforth '1914 Military Manual'), 244, cited in Eyal Benvenisti and Amichai Cohen, 'War is Governance: Explaining the Logic of the Laws of War from a Principal-Agent Perspective' (2014) 112 Michigan Law Review 1363, 1370.

${ }^{21}$ Isabel V. Hull, A Scrap of Paper: Breaking and Making International Law during the Great War (Cornell University Press 2014) 83-84.

${ }^{22}$ Geneva Convention for the Amelioration of the Condition of the Wounded and Sick in Armies in the Field, 6 July 1906 (entered into force 9 August 1907) art 26.

${ }^{23}$ Hull (n 21) 85.

${ }^{24}$ Huw Bennett, Fighting the Mau Mau: The British Army and Counter-Insurgency in the Kenya Emergency (Cambridge University Press 2012) 63; Leslie C. Green, The Contemporary Law of Armed Conflict (3rd edition, Manchester University Press 2008) 338.

${ }^{25}$ Bennett, (n 24) 63, 74.
} 
was delayed and unlikely to have included all ranks, 'military law', including aspects of military justice (but not expressly international law) taught at the Royal Military Academy Sandhurst from 1950 onwards. ${ }^{26}$ There are brief references in case law and scholarship to the 'limited training' in general of National Servicemen deployed to Malaya in 1948, where 24 unarmed civilians were killed by the members of the Scots Guards in the village of Batang Kali. ${ }^{27}$ Case law makes similarly brief references to the impossibility of training guards in 'hastily constructed' detention camps in Kenya (1952-1960). ${ }^{28}$

Why was instruction in IHL apparently delayed? There are three explanations. First, the government was keen to argue that IHL did not apply to colonial warfare. Britain had been the only state at the 1899 Hague Conference to argue that dum-dum bullets should be permissible in colonial warfare, ${ }^{29}$ and the 1914 Manual emphasises that 'International Law appl[ies] only to warfare between civilised nations... [not to] wars with uncivilised States and tribes. ${ }^{30}$ Archives also reveal a denial that Britain's colonial deployments were armed conflicts at all, whether international or non-international. Instead, they are termed 'internal disturbances', 'uprisings', or 'emergenc[ies].' Archival research for this article shows that in 1956, the Foreign Office was opposed to an International Committee of the Red Cross (ICRC) resolution on internal conflicts, in case this meant that the ICRC could visit prisoners in the UK's colonial territories. ${ }^{31}$ The Foreign Office wrote that such violence should be classed as an 'internal disturbance', neither international nor non-international armed conflict; and asked the British Red Cross Society (BRCS) delegation to oppose the ICRC resolution, recalling ' $[\mathrm{t}]$ he circumstances in which ... it has been found necessary to resort to collective punishment in Malaya and Kenya..., 32 The date is significant, as 1956 was a year prior to the UK's ratification of the Four Geneva Conventions. The government was aware that its policies in Malaya and Kenya would have violated the IHL of international and

\footnotetext{
${ }^{26}$ ibid., 73.

${ }^{27}$ Keyu and Others $v$ Secretary of State for Foreign and Commonwealth Affairs and another [2015] UKSC 69, para

7; Keyu and Others v. Secretary of State for Foreign and Commonwealth Affairs and Another [2014] EWCA Civ

312, paras 20-21; Victoria Nolan, Military Leadership and Counterinsurgency: The British Army and Small War Strategy Since World War II (IB Tauris 2011) 215.

${ }^{28}$ G.H. Heaton, report of the former Commissioner of Prisons in Kenya, July 1956, excerpted in Ndiki Mutua and Others v. Foreign and Commonwealth Office [2012] EWHC 2678, para 127.

${ }^{29}$ Frédéric Mégret, 'From 'Savages' to 'Unlawful Combatants': A Postcolonial Look at International Humanitarian Law's' Other"' in Anne Orford (ed), International Law and its Others (Cambridge University Press 2006) 275.

${ }^{30} 1914$ Military Manual, cited in Mégret (n 30) 279.

${ }^{31}$ Memo from the Foreign Office, sent to Miss Evelyn Bark of the British Red Cross Society (BRCS), 5 June 1956 (British Red Cross Archive), para 3.

32 ibid., para 6.
} 
non-international armed conflict, if it had accepted IHL's de jure applicability to Kenya and Malaya.

Second, the government resisted the development of the IHL of NIAC. Travaux préparatoires show the UK's 'open hostility' to Common Article 3 to the Four Geneva Conventions, in case it might be applied to colonial conflicts; a significant cause of the UK's delay in ratifying the Geneva Conventions until 1957. ${ }^{33}$ It was not until 1998 that the UK ratified the Additional Protocols to the Geneva Conventions, after the end of the Troubles in Northern Ireland. This reflects not only a concern about AP I's field of application (Article 1(4) provides that conflicts fought against colonial regimes, alien occupation or racist regimes should be classified as IAC instead of NIAC) but also the government's sustained position that the Troubles did not amount to an armed conflict at all. In contrast, Haines argues, applying Article 1(2) of AP II, that the violence reached the threshold of a NIAC between 1971 and 1974, especially during 1972. ${ }^{34}$ The UK's interpretive declaration on Article 1(4) AP I of 2 July 2002reads as follows::

...the term "armed conflict" of itself and in its context denotes a situation of a kind which is not constituted by the commission of ordinary crimes including acts of terrorism whether concerted or in isolation. ${ }^{35}$

Third, archival research for this article suggests that IHL training was delayed in part because of the government's commitment to the nuclear deterrent. The British Red Cross Society acknowledged the incompatibility between the Four Geneva Conventions and any use of nuclear weapons in its correspondence with the government ${ }^{36}$ A former military lawyer, G.I.A.D. Draper also believed that the nuclear deterrent had delayed the implementation of the IHL training obligation. Having concluded that Parliament may have been misled when Ministers asserted that IHL training was taking place, Draper reached the 'painful and reluctant conclusion' that the Service Departments knew IHL instruction could jeopardise acceptance of the legality of 'nuclear and thermo-nuclear weapons', and that that explained the delayed implementation of the IHL

\footnotetext{
${ }^{33}$ Bennett (n 24) 66.

${ }^{34}$ Steven Haines, 'Northern Ireland: 1968-1998' in Elizabeth Wilmshurst (ed), International Law and the Classification of Conflicts (Oxford University Press 2012), 134, 143.

${ }^{35}$ UK Reservation to AP I d), 2 July 2002, available at the ICRC Treaty Database: https://ihldatabases.icrc.org/applic/ihl/ihl.nsf/Notification.xsp?action=openDocument\&documentId=0A9E03F0F2EE757CC1 256402003FB6D2

${ }^{36}$ Letter from I.D.M. Reid Esq, Assistant Secretary-General of the BRCS, 3 August 1961, enclosing Draft Rules for the Limitation of the Dangers Incurred by the Civilian Population in Time of War (British Red Cross Archive).
} 
training obligation. ${ }^{37}$ However, the relevant archive shows only Draper's letter to the BRCS on this point; no reply, nuance or disagreement.

Absent or perfunctory training in IHL correlated with recurrent allegations of torture and illtreatment by British troops, in deployments from the 1950s to the 2000s. This correlation is stronger in counterinsurgency deployments and NIAC: Kenya, Aden, Cyprus, and Northern Ireland, although allegations of torture and other ill-treatment were also made in Afghanistan and Iraq. There were fewer such allegations in the IAC in the Falklands and the 1991 conflict in Iraq. In the Falklands, British troops were found to have forced Argentinian prisoners of war to move unstable napalm (a weapon held by Argentinian forces). An investigation showed that the soldiers should have been aware of their obligations under the Third Geneva Convention, but their training was deficient in this respect. ${ }^{38}$ The methods of torture and ill-treatment recurred between conflicts, suggesting that soldiers were trained in how to torture detainees, while there is little evidence that they were trained in the IHL prohibitions of torture and either inhuman or cruel treatment (in IAC and NIAC respectively).

During the violence in Kenya from 1952-1960, approximately 150,000 suspected Mau Mau insurgents were detained, suffering beatings, stress positions, rape and mutilation including castration. ${ }^{39}$ Despite a $£ 14 \mathrm{~m}$ settlement in 2013 , subsequent group litigation was terminated in 2018 in Kimathi, when the judge declined to extend s33 Limitation Act $1980 .{ }^{40}$ In January 2019, the government reached a $£ 1$ million settlement with 33 torture victims detained in the Eoka uprising in Cyprus from 1955-1959. ${ }^{41}$ The ICRC and the European Commission for Human Rights had each been seized of complaints of 'ill-treatment' in detention and in interrogation during the Cyprus 'emergency', the latter through an application by Greece. ${ }^{42}$ The UK continued to deny IHL's applicability to Cyprus. Drohan cites an unpublished letter from a former soldier to a newspaper in 1958, and subsequent correspondence between the newspaper editor and the Ministry of Defence. The soldier wrote that he had been trained that it would be 'necessary' to use certain

\footnotetext{
${ }^{37}$ Letter from Gerald Draper to Mr Reid of the BRCS, 15 July 1961 (received by Captain Liddell Hart on 10 August 1961, Liddell Hart Archive, King's College London).

${ }^{38}$ HL Deb 15 December 1993 vol 550 cc1379-403.

${ }^{39}$ Caroline Elkins, Imperial Reckoning: The Untold Story of Britain's Gulag in Kenya (Henry Holt 2005).

${ }^{40}$ Kimathi and Others v The Foreign and Commonwealth Office [2018] EWHC 3144.

${ }^{41}$ Evie Andreou, 'UK Govt Settles "David and Goliath” Eoka Torture Case (Update 2)' Cyprus Mail (23 January 2019).

${ }^{42}$ The Greek case, Commission Report, 5 November 1969, Yearbook of the European Convention on Human Rights XII (1969).
} 
torture techniques on Eoka detainees, but only those which would not leave physical marks, to preclude inquiry by the ICRC. ${ }^{43}$

In Aden, the High Commissioner permitted ICRC intervention and allowed limited reforms. The Bowen Report from 1967 led to an amended Joint Directive on Military Interrogation in Internal Operations Overseas, which paraphrases most of Common Article $3 .{ }^{44}$ Bennett argues that this 'brought reputational benefits', making concessions to the ICRC's confidential good offices while attempting to undermine public allegations of torture by Amnesty International. ${ }^{45}$ Yet the Aden case study shows 'forced wall standing, enforced nakedness, and beatings', ${ }^{46}$ similar to the recurring stress positions and assaults suffered by those interned in Northern Ireland ${ }^{47}$ and detainees in Iraq. ${ }^{48}$

Similar torture was suffered by detainees in Kenya, Cyprus, Aden, Northern Ireland and Iraq, suggesting patterns of violation in British state practice, and an institutional memory of torture and ill-treatment that merely correlates with absent or perfunctory training in IHL. The narrative in the Baha Mousa Public Inquiry report that the 1973 prohibition on the 'five techniques' had been simply forgotten as a result of a failure of institutional memory and deficient training becomes less plausible. Yes, IHL training was deficient, but this is not a monocausal explanation. Recurrent patterns of torture and ill-treatment highlight the importance of IHL training but also its limits. Mere dissemination of IHL prohibitions will be insufficient to prevent deliberate violations of IHL and IHRL in armed conflict. As I argue elsewhere, there is a predictive gap between communicated norm and subsequent behaviour; and IHL training must take account of cognitive and volitional aspects: soldiers' and officers' understanding of IHL and their willingness to comply. ${ }^{49}$

The Individual Training Directive (Army), in versions from 1998 and 2003, provided that one period of 40 minutes annually should be devoted to knowledge of the law of armed conflict

\footnotetext{
${ }^{43}$ Brian Drohan, Brutality in an Age of Human Rights: Activism and Counterinsurgency at the End of the British Empire (Cornell University Press 2018).

${ }^{44}$ Michael O’Boyle, 'Torture and Emergency Powers under the European Convention on Human Rights: Ireland $v$. the United Kingdom' (1977) 71 American Journal of International Law 674.

${ }^{45}$ Huw Bennett, "'Detainees Are Always One's Achilles Heel”: The Struggle over the Scrutiny of Detention and Interrogation in Aden, 1963-1967' (2016) 23 War in History 457, 464, 487.

46 ibid., 486.

${ }^{47}$ Ireland v United Kingdom (1978) 2 EHRR 25, Ireland v United Kingdom [2018] ECHR (GC) Application no. 5310/71.

${ }^{48}$ Al-Skeini \& Others $v$ the United Kingdom [2011] European Court of Human Rights (Grand Chamber) Application no. 55721/07, [2011] ECHR 1093; Alseran, Al-Waheed and Others v Ministry of Defence [2018] 3 WLR 95.

${ }^{49}$ Stubbins Bates, PhD thesis, 2017 (n 5).
} 
(LOAC) $;^{50}$ while 23.5 periods of 40 minutes, over 15 hours was devoted to weapons training. The training time devoted to learning about LOAC was half that given to learning about the risks of substance misuse. ${ }^{51}$ In 1998, this annual training comprised a pamphlet on LOAC, supplemented by a 'brief explanation of the different roles of the soldier in peace support operations'. ${ }^{52}$ Field exercises using scenarios which incorporated LOAC were a possibility for mission-specific/predeployment training. ${ }^{53}$ In 2003, the annual training had expanded from the pamphlet, also to include an Aide-Mémoire in Annex B to the pamphlet on LOAC, a 15 minute film and 24 slide PowerPoint lecture. ${ }^{54}$ Both Directives foresee a train-the-trainers model, with Army lawyers available to provide advice and guidance, and non-lawyer officers (warrant officers, senior noncommissioned officers) training soldiers and junior non-commissioned officers within their unit. ${ }^{55}$ As these officers would have been trained in brief annual sessions at earlier stages in their career, it is questionable whether their knowledge had sufficient depth to impart it to soldiers in their command. Contemporaneous accounts suggest passive learning, with some resentment of IHL training: trainers would be 'reading out a badly-scripted PowerPoint...half-heartedly as if the entire thing is a tiresome imposition standing between them and tea and toast. ${ }^{, 56}$

\section{B. Changes to Training after the Baha Mousa Public Inquiry Report}

The Baha Mousa Public Inquiry found that deficient IHL training in 2003 contributed to the inhuman treatment of detainees, and to Baha Mousa's death. The Inquiry found a gap in doctrine, and a failure to 'instil... lasting knowledge' 57 of the prohibition of the 'five techniques' (hooding, wall-standing or stress positions, subjection to white noise, deprivation of sleep, deprivation of adequate food) in the case of Ireland v. $U K,{ }^{58}$ At Sandhurst, the training was longer, but still 'at a level of broad generality and there is no indication that it covered the prohibition on the five

\footnotetext{
${ }^{50}$ Individual Training Directive (Army) (ITD (A)) 6 - The Law of Armed Conflict (LOAC) 1998, para 8; ITD(A) 6

LOAC 2003, para 7. The Army prefers 'LOAC' to 'IHL'.

${ }^{51} \operatorname{ITD}(\mathrm{A})$ 1998, 5-6

52 ITD(A) 6 LOAC 1998, para 8

53 ibid.

${ }^{54}$ ITD(A) 6 LOAC 2003, paras 7, 13.

55 ITD(A) 6 LOAC 1998, para 10; ITD(A) 6 LOAC 2003, para 9.

56 'Lawyers to Right of Them, Lawyers to Left of Them', The Economist, 9 August 2014, comment by Camberley4PQ (a pseudonym for a former Army lawyer).

${ }^{57}$ Gage (n 15) Part XVIII, para 305.

${ }^{58}$ Ireland v. United Kingdom, ECtHR (Application No. 5310/71), Judgment, 18 January 1978; Gage (n 15), Summary, para 302, 205, Part I, I.81.
} 
techniques. ${ }^{59}$ A causal thread was drawn between the brutalising effects of conduct-after-capture training, in which personnel experienced simulations of the torture and ill-treatment they might face as prisoners of war, without sufficient emphasis that these techniques were prohibited and must not be re-enacted upon Iraqi prisoners of war and civilian internees. ${ }^{60}$ Under the Individual Training Directive 2003, soldiers received 40 minutes of annual training in IHL, much of it based on a Cold War-era video, which was 'somewhat perfunctory', ${ }^{61}$ and offered little training for the asymmetric warfare they faced in Iraq. Witnesses reported forgetting the IHL they had been taught. Of the 30 witnesses who had attended the Army Staff Course, only three 'gave evidence indicating they specifically remembered' the prohibition of the 'five techniques'. ${ }^{62}$ The Joint Committee on Human Rights (JCHR) found that the Payne court martial (accepted by the Crown) and the Aitken report suggested that 'the prohibition on the use of conditioning techniques may have been interpreted narrowly, as only applying to interrogation personnel and to operations in Northern Ireland'. ${ }^{63}$ This was contrary to earlier evidence the JCHR had received from military and Ministerial sources. The Baha Mousa Public Inquiry revealed differing understandings among soldiers of what constitutes 'humane treatment', ${ }^{64}$ although all witnesses agreed that detainees must be treated 'humanely'. ${ }^{65}$ In particular, witnesses to the Inquiry had inconsistent understandings of whether or not sight deprivation was permitted through blindfolding or hooding, ${ }^{66}$ and there was evidence of ' $[\mathrm{u}]$ nauthorised and informal' training on Conduct After Capture. ${ }^{67}$ Training in interrogation 'included direct insults and permitted racist and homophobic abuse... also included the use of indirect threats to instil fear. ${ }^{96}$

The Ministry of Defence (MOD) accepted 71 of the 73 recommendations in the Baha Mousa Public Inquiry Report, initially accepting 72. When the Report was published, the then Defence Secretary acknowledged the 'shocking displays of brutality' from British service personnel, and that 'violent and cowardly abuse and assaults' as identified in the Report were the cause of Baha

\footnotetext{
${ }^{59}$ Gage, Part XVIII, note 100, para 300.

60 ibid., Part VI, paras 6.360-6.361.

61 ibid., Part XVIII, para 310.

62 ibid., para 305

63 JCHR, 28 ${ }^{\text {th }}$ Report, 15 July 2008, Discrepancies in evidence given to the Committee, paras 13-16.

${ }^{64}$ Gage, Part XVIII, , para 302.

65 ibid., Part I, para 1.81.

66 ibid., para 316, 338.

67 ibid., para 323.

68 ibid., para 317.
} 
Mousa's death, with deficits in training as part of the context. ${ }^{69} \mathrm{He}$ accepted all the Report's recommendations with the exception of 'a blanket ban ... on certain verbal and non-physical techniques'.$^{70}$ By the time of the Report's publication, the MOD had renamed and adapted the 'harsh' approach to tactical questioning to 'challenge direct' and 'challenge indirect', which the Court of Appeal found to have adequate safeguards to be lawful under Article 3 ECHR. ${ }^{71}$ Subsequently, the Minister for the Armed Forces announced that Recommendation 44 (of external inspection of military detention facilities, perhaps by Her Majesty's Inspector of Prisons) would also be rejected. ${ }^{72}$

There was a succession of statements before and after the Baha Mousa Public Inquiry Report's publication to indicate that reforms to IHL training were in progress or complete. None of them addressed individual recommendations relating to IHL training; these were blanket assertions. In March 2014, it was asserted that the MOD had 'taken action to consider and address all the accepted recommendations in the report. ${ }^{73}$ In a Government Response to a Defence Select Committee report shortly thereafter, the recommendations were said to have been 'implemented' ${ }^{74}$ In the MOD's Closing Submissions to the Al-Sweady Public Inquiry (also in 2014), the term 'implemented' is used again, with Recommendation 44 described as 'accepted and implemented', because consideration was given to the recommendation, but it 'did not lead to any policy change' ${ }^{75}$

The use of the terms 'implemented' and 'addressed' interchangeably suggests some ambiguity. 'To implement' refers to putting a decision or plan into action, or fulfilling an undertaking; while 'to address' refers to 'think[ing] about and begin[ning] to deal with' a particular issue. ${ }^{76}$ Research for this article shows that these assertions were at least partially misleading. The February 2014 Operational Law Training Directive (which is more ambitious than but included most of the training-related recommendations of the Baha Mousa Public Inquiry Report) had not been fully negotiated with the chain of command at the time of these assurances. It was not until April 2015

\footnotetext{
${ }^{69}$ HC Deb 8 September 2011, col 571.

70 ibid., col. 572.

${ }^{71} R$ (Haider Ali Hussein) v Secretary of State for Defence [2014] EWCA Civ 1087.

${ }^{72}$ HC 27 March 2014, col 32WS.

73 ibid.

${ }^{74}$ UK Armed Forces Personnel and the Legal Framework for Future Operations: Government Response to the Committee's Twelfth Report of Session 2013-14 (Defence Select Committee HC 2014, 931), Annex, para 9.

${ }^{75}$ Sanders et al (n 16) paras 1096-1097.

76 Oxford English Dictionary, 'implement' (v.); 'address' (v.).
} 
that the Operational Law Training Directive was introduced without amendment into the MATT 7 instructional materials for 2015-2016. ${ }^{77}$

Instead, there were gradual changes to training from 2004-2011, and more comprehensive improvements from 2012-2017. The Aitken Report acknowledged that in 2004, pre-deployment training on detainee handling was changed to include a specific prohibition on hooding. ${ }^{78}$ In 2005 , and again in 2007, two editions of a confidential Ministry of Defence Policy on Tactical Questioning and Interrogation: Support to Operations were produced. ${ }^{79}$ Soldiers who completed conduct after capture (CAC) training before 2003-4 had to be 'revalidat[ed]' before they could conduct interrogation and tactical questioning. ${ }^{80}$ In 2006, an Operational Law Branch was established, inter alia 'to improve the quality of legal advice in training' and to 'review... all material taught in both the adaptive foundation and on pre-deployment training. ${ }^{81}$ This led to the introduction of the first MATT, also in $2006 ;{ }^{82}$ In 2006, LOAC training was combined with Values and Standards, Substance Misuse and Equality and Diversity awareness, with LOAC taught in a 22-minute video and tested in 10 multiple choice questions. ${ }^{83}$ This was the first time LOAC knowledge was tested. ${ }^{84}$

In 2008, LOAC was given its own MATT, but many of the multiple-choice questions reflected policy and not law, e.g. 'What is the main reason why you should always treat the local population humanely?' was correctly answered by 'It will help to win the battle for hearts and minds.' There is no reference to binding IHL, nor to the specific duties involved in 'treat[ing]' them 'humanely'. ${ }^{85}$ The past papers broach the issues of unlawful orders and the prohibition on ordering that there be no survivors, but the multiple-choice format (still in use) does not test depth of understanding or the ability to apply knowledge in diverse operational circumstances. In 2010, the Army Inspectorate Review found 'no evidence to suggest that pre-deployment and in-theatre training are

\footnotetext{
${ }^{77}$ Email communication with ALS, 8 April 2015, 14 May 2015 (on file with the author).

${ }^{78}$ Aitken (n 17), para 20.

${ }^{79}$ Ministry of Defence Policy on Tactical Questioning and Interrogation: Support to Operations, $2^{\text {nd }}$ edition, 31 January 2007, cited in Aitken, para 21.

80 ibid.

81 ibid., para 31.

${ }^{82}$ Defence Information Note (2006), establishing the Military Annual Training Test (MATT) in the Law of Armed Conflict, cited in Aitken (n 17) para 25.

${ }^{83}$ MATT 6 Answer Bank, April 2006.

${ }^{84}$ MOD, Aitken Review - Measures to Prevent Abuse on Operations since 2003 -Updated, submitted to the Baha Mousa Public Inquiry, 17 February 2010, 3.

${ }^{85}$ MATT 7 Operational Law Answer Bank 2008, q 23.
} 
failing to prepare forces to carry out detainee handling,${ }^{9}{ }^{86}$ but the materials used for these trainings are classified, so remain inaccessible to independent research or Parliamentary scrutiny. Specific wrong answers might have misled soldiers, with a question from 2011 implying that rules of engagement (ROE) or the presence of medical personnel could authorise hooding prisoners. ${ }^{87}$

The period up to and including 2011 shows gradual improvements, and assertions that all is now well with the British Army's IHL training. The Consolidated Guidance to Intelligence Officers and Service Personnel was published in November 2011, ${ }^{88}$ just after the Baha Mousa Public Inquiry Report, but this document was subject to review by the Investigatory Powers Commissioner, and critique by the UN Committee against Torture. ${ }^{89}$ The $2^{\text {nd }}$ edition of JDP 1-10 (2011) refers to the prohibition of the five techniques in all operations, implementing one of the recommendations of the Baha Mousa Public Inquiry.

2012 is a subtle turning point in military training on international law. MATT 7 test papers included a useful gauge of soldiers' and officers' understanding of command responsibility and their duty to report violations, and a question to elicit misunderstandings of reciprocity. ${ }^{90}$ Issue 5 (2013) of the MATT 7 included audio-visual instruction on detainee handling that was a marked improvement on previous iterations, implementing numerous recommendations from the Baha Mousa Public Inquiry. ${ }^{91}$ There were further improvements in the breadth and depth of IHL training, and in protections for CPERS with the Operational Law Training Directive of February 2014, its implementation in a comprehensively expanded MATT 7 in 2015, and the $3^{\text {rd }}$ edition of JDP 1-10 on CPERS, also in 2015. The latter document includes valuable personnel screening tools as a technique to prevent torture and inhuman treatment in British military detention; shows awareness of the risks of ill-treatment from racist epithets; and urges command responsibility and

\footnotetext{
${ }^{86}$ Army Inspectorate Review into the Implementation of Policy, Training and Conduct of Detainee Handling, 15 July 2010.

${ }^{87}$ MATT 7 Operational Law Answer Bank 2011.

${ }^{88}$ Consolidated Guidance to Intelligence Officers and Service Personnel on the Detention and Interviewing of Detainees Overseas, and on the Passing and Receipt of Intelligence Relating to Detainees, November 2011.

${ }^{89}$ CAT, Concluding Observations (n 18), para 36.

${ }^{90}$ MATT 7 Operational Law Answer Bank 2012, q 7, 5.

${ }^{91}$ MATT Policy Update, DTrg(A)/TrgPolPlans/25/1, 27 March 2013.
} 
an obligation to report instances of ill-treatment. ${ }^{92} \mathrm{~A} 4^{\text {th }}$ edition was due in $2019,{ }^{93}$ but is not yet published.

From 2016 onwards, MATT 7 included a second Module on Investigations and Accountability, setting out the criminal sanctions that might follow a violation of operational law. Also from 2016, training on CPERS has a practical component: a CPERS Handling Drill must be included in basic and continuation training for all ranks, in mission-specific (pre-deployment) training and in-theatre training for troops who miss the pre-deployment training. ${ }^{94}$ The classroom-based and practical CPERS training are prima facie evidence of the UK's commitment towards preventing a recurrence of the crimes faced by Baha Mousa and those detained with him.

\section{Content}

The Operational Law Training Directive 2014 is both broad and detailed in its IHL content; and applies to all 'individual, collective or mission specific training'. ${ }^{95}$ Only the specialist education of ALS officers is outside its scope. ${ }^{96}$ There is emphasis on the 'command responsibility' to ensure that operational law training is implemented in accordance with the Directive, and the chain of command must ensure the completion and auditing of MATT $7 .{ }^{97}$ The aim is to make LOAC part of general training, so it 'seeps in' and becomes 'second nature'. ${ }^{98}$ The Directive retains a train-the-trainer model, and a standardised, scripted approach, where (if an Army lawyer is unavailable) non-lawyer officers read out verbatim notes to support PowerPoint slides: MATT 7 must be shown in full and the script followed to ensure that the training objectives are met.' 99 This approach guards against variation in the norms trained, but continues a passive dissemination model, with a risk of IHL concepts being misunderstood or mistakenly clarified. Under MATT 7, instructors are 'encouraged to add emphasis' to the compulsory script 'with examples from

\footnotetext{
92 Joint Doctrine Publication (JDP) 1-10 Captured Persons (CPERS) (3rd ed, 2015) paras 521-523, Annex 5A; paras $520,504$.

${ }^{93}$ Systemic Issues identified from Service Police and Other Investigations into Military Operations Overseas, August 2018, notes 9-10.

${ }^{94}$ Army Briefing Note, Introduction of the Captured Persons (CPERS) Handling Drill and Mandated Unit CPERS Appointments, 11 December 2015.

${ }^{95}$ Operational Law Training Directive (OpLaw TD) February 2014, para 6.

96 ibid.

${ }^{97}$ ibid., paras 3, 9f).

${ }^{98}$ Meeting, ALS, October 2014.

${ }^{99}$ OpLaw TD, para 10.
} 
practical experience. ${ }^{100}$ This discretionary element needs careful scrutiny in practice; lest the examples shared might lead soldiers and officers to question the prohibitions in the training script.

The Directive has comprehensive aims for LOAC knowledge. These are detailed in Operational Performance Statements and Formal Training Statements in the Annexes, and differentiated approximately by 'generic soldier' and 'generic officer'. ${ }^{101}$ The difference between IAC and NIAC must be understood, alongside the principles of military necessity, humanity, distinction and proportionality. ${ }^{102}$ Both soldiers and officers must be able to identify military objectives and civilian objects; to act appropriately to all categories of persons (the training materials refer to combatants, civilians and refugees); to understand and respond accordingly to civilians directly participating in hostilities and the concept of levée en masse. ${ }^{103}$ Both soldiers and officers must be able to identify and abide by prohibitions on certain weapons, and understand perfidy and ruses, and the prohibition on using civilian shields. ${ }^{104}$ They must understand and comply with rules on target identification, precautions and warnings before an attack and determine responsibility for ending an attack which might be indiscriminate. Civilian objects, cultural property, medical facilities, and work and installations containing dangerous forces must all be recognised and protected. ${ }^{105}$ Rules on a range of protective emblems, white flags, truce and surrender must all be understood, and their misuse identified. ${ }^{106}$ Soldiers and officers must both know how to differentiate a military objective and a civilian object, limiting attacks to military objectives only. LOAC protections must be given to civilians, medical and religious personnel. ${ }^{107}$

Rules relating to protected persons, including the wounded, sick, shipwrecked, and CPERS (prisoners of war, civilian internees, and other detainees) must be understood; and each of the five techniques are set out as prohibitions which must be understood. Soldiers and officers must both identify correct questioning and handover procedures for CPERS, and report abuse or death 'to the chain of command and Service Police' without delay. ${ }^{108}$ These training requirements implement several recommendations of the Baha Mousa Public Inquiry. Personnel must

\footnotetext{
100 MATT 7 (2015), para 2.3

101 ibid., Annexes A-D.

102 Operational Performance Statements and Formal Training Statements, categories 1-3.

103 ibid., categories 4-5.

104 ibid., categories 6.

105 ibid., categories 7-8.

106 ibid., category 9.

107 ibid., categories 10, 13 .

108 ibid., categories 11-12.
} 
understand that they have the responsibility to intervene if a LOAC violation is in progress, and to recognise and report LOAC violations, war crimes, crimes against humanity and genocide. ${ }^{109}$ Soldiers and officers must be able to identify an unlawful order, and to know that they must follow lawful orders while not following unlawful orders. ${ }^{110}$ Warrant Officers and above must be able to '[r]ecognise what action should be taken in response to an unlawful command'. The training requirements to identify and act upon command responsibility are sensibly greater for officers than soldiers, who must also 'issue lawful orders, ... [a]pply command responsibility for the actions of subordinates... [and i]nterpret state accountability for LOAC violations.' ${ }^{111}$ Knowledge requirements on the use of force and ROE follow. ${ }^{112}$

In an important statement of opinio juris, the co-applicability of IHL and IHRL is recognised as possible, particularly in NIAC, but the parameters for co-applicability have not been fully settled. ${ }^{113}$ Knowledge of human rights 'principles' applicable in armed conflict is also stipulated, but the knowledge required is imprecise and general. Soldiers and officers must recognise the framework of human rights law, to whom it applies, the 'implications of breaching basic human rights principles', and must 'carry out the process of reporting human rights violations. ${ }^{114}$ There is very little precision here: do 'basic human rights principles' acknowledge binding international law? Does it refer only to civil and political rights, or to economic, social and cultural rights as well? If only the former, how are the 'basic ... principles' identified? Only the Convention on the Rights of the Child is included in the Formal Training Statements: there is no mention of the Human Rights Act 1998, nor the obligation in Article 10 of CAT to train anyone from 'civil or military' law enforcement, or anyone who would have custody of a detainee in the prohibitions therein.

The Directive implies by omission that IHL consists of the law of IAC and belligerent occupation. It is silent on the law of NIAC, except for the requirement that soldiers and officers 'identify the difference' between IAC and NIAC; ${ }^{115}$ and one reference to Additional Protocol II, which appears as part of a non-exhaustive list of treaties. ${ }^{116}$ As the IHL of IAC offers more detailed

\footnotetext{
109 ibid., categories 13-14.

110 ibid.

111 Training Performance Statement (Officer), para 15.

112 ibid., categories 16-18.

113 OpLaw TD, Annexes, 99, n 33.

114 Training Performance Statement (Officer), category 19.

${ }^{115}$ Formal Training Statements, category 2.2.

${ }^{116}$ Formal Training Statement (Soldier), n32.
} 
protections than the IHL of NIAC, it speaks to the ambitions of the Directive's authors for comprehensive IHL training. Questions of conflict classification are the domain of predeployment, mission-specific training. The MOD will decide on the classification of a conflict, and will decide upon the customary IHL to apply as part of confidential ROE. This leaves open the possibility that selected norms from the IHL of IAC will be applied to a NIAC as customary IHL, improving the protections granted to non-combatants as compared to treaty law alone.

From 2015, MATT 7 integrates the requirements of the Operational Law Training Directive, includes relevant IHRL norms in the Module on CPERS and the Use of Force, and from 2016, includes Investigations and Accountability. ${ }^{117}$ Each year, all personnel must pass the first three Modules, while staff in deployable roles (including Reserves warned for operations) must also pass the fourth, on the Use of Force. ${ }^{118}$ Soldiers receive almost three hours of training across MATT 7's four Modules. ${ }^{119}$ These latest reforms to IHL training offer a comprehensive approach to classroom-based instruction, with video and e-learning tools to help soldiers who struggle with literacy or classroom-based instruction. ${ }^{120}$ The 2017 materials blend textbook narration of IHL provisions with film clips on weapons, tactics, protected persons and objects, and glossaries of core principles. ${ }^{121}$

The Module on Investigations and Accountability was apparently created for structural reasons, to move material already present in an over-long LOAC Module. ${ }^{122}$ However, it has substantive impact beyond this, training troops in IHL's due diligence norms, and clarifying the ICC's jurisdiction and that of national courts. The Module emphasises the obligation to disobey unlawful orders (first asking for 'clarification or explanation'), ${ }^{123}$ to intervene to end a war crime being committed by UK personnel ('if you judge it safe to do so') ${ }^{124}$ and to report war crimes by UK personnel (reassuring soldiers that there should be no repercussions for doing so). ${ }^{125}$ Ranks above lance corporal have command responsibility to ensure that subordinates understand their

\footnotetext{
${ }^{117}$ HC 21 March 2016, col 31271W.

118 ibid., MATT 7 issue 9 (2017), 3.2.1-3.2.11.

${ }^{119}$ MATT 7 (2015-2017) Operational Law Policy Statement, 1.1, para 13.

${ }^{120}$ Defence Committee, The Armed Forces Covenant in Action? Part 4: Education of Service Personnel (20132014) 17: of those recruited to the Army in 2012, 39\% had an 11-year old's level of literacy.

${ }^{121}$ MATT 7 issue 9 (2017), Part I, Presentation 1; Army Legal Services, email on file with the author, 25 March

2019: confirming that there have been no structural or substantive updates since issue 9 (2017).

${ }^{122}$ Email correspondence with ALS, 11 May 2017 (on file with the author).

${ }^{123}$ MATT 7 issue 9 (2017) 3.2.4.

124 ibid.

125 ibid., 3.2.5.
} 
LOAC obligations; to report, and if necessary, stop war crimes committed by their subordinates. Module 2 begins to correct the view that only 'other' armed forces and armed groups commit violations of IHL; as recommended by the Baha Mousa Public Inquiry. Briefly, it also addresses the risk of violations perpetrated through a sense of false reciprocity ('You are never allowed to breach the law just because the enemy has done so'). ${ }^{126}$ The Module has an individual and command responsibility film clip in issue 9 (2017). ${ }^{127}$ The test papers also reflect on individual and command responsibility, with one showing an image from the case of Camp Breadbasket, in which Iraqi looters suffered a range of ill-treatment, and asking 'What would you do?' 128

From 2013 onwards, the lecture on CPERS has defined prohibited stress positions ("painful, extremely uncomfortable or exhausting to maintain'), the prohibition of hooding ('at any time and for any purpose'), and required humane treatment ('all CPERS must be protected from assault, abuse, and any other humiliating or degrading treatment' $)^{129}$ to reflect the recommendations of the Baha Mousa Public Inquiry Report, but not quite to attain the standards in Article 17 of the Third Geneva Convention, in which prisoners of war who refuse to answer questions 'may not be threatened, insulted, or exposed to any unpleasant or disadvantageous treatment of any kind. ${ }^{130}$ In the 2013 version, the definition of 'humane treatment' did not expressly prohibit sexually degrading acts; but the current instructors' script does so (see section 4 below). Physical vulnerability was acknowledged more readily: ‘...some CPERS may be vulnerable persons, and special rules may apply to them.' 131

The script on CPERS in the 2015 MATT 7 explains the risks for positional asphyxia and the need for medics to be available. ${ }^{132}$ While this implements the recommendations of the Baha Mousa Public Inquiry, it sits uneasily with the clear definition and prohibition of stress positions in the audio-visual materials on captured persons from 2013 onwards, as there should be no risk of positional asphyxia from stress positions if stress positions are never used. The prohibition on verbal abuse is briefly acknowledged: 'CPERS must not be abused either physically or verbally....' 133 The 2017 instructors' script distinguishes between prohibited stress positions, and

\footnotetext{
126 ibid., 3.2.3.

${ }^{127}$ FOI request pending.

${ }^{128}$ MATT 7 test paper Level 1 Year 4 p2, q18

${ }^{129}$ MATT 7 (2013) CPERS.

${ }^{130}$ GC III, art 17.

${ }^{131}$ MATT 7 (2013) CPERS audio-visual materials.

${ }^{132}$ MATT 7 (2015) CPERS PowerPoint.

133 ibid.
} 
restraint positions which might be 'necessary where an individual is attempting to escape or assaults' their handlers or interrogators. ${ }^{134}$ Section 4 below critiques the confusion that this text might create, as restraint positions are left undefined. The script requires soldiers to allow detainees to 'change position regularly to prevent pain, extreme discomfort or exhaustion' (i.e. to prevent a restraint position from reaching the perceived threshold of a stress position), and to apply restraint positions 'only... for the minimum period necessary to complete the task'. Those guarding the detainee must 'take care to ensure that a restraint position does not inhibit the CPERS' ability to breathe', ${ }^{135}$ and to be aware of restraint positions which might 'compromise... the airways or expansion of the lungs (e.g. in the prone position)', and that a detainee may be able to 'speak or shout' and still be asphyxiating. Consequently, '[n]o CPERS should be restrained face down for longer than is absolutely necessary to gain control'. ${ }^{136}$ There are some safeguards (imprecisely expressed) against the abusive use of 'strip searches and body cavity searches', which must 'only be carried out in limited circumstances by trained and qualified personnel.' 137

Reciprocity appears in relation to CPERS' nutrition and medical treatment. CPERS should have three meals a day; soldiers can ration detainees' water or food if that also applies to UK forces ('If you are on rations, then so are they.') ${ }^{138}$ In the audio-visual materials, an actor playing a soldier is overheard saying (at the point of capture) 'D'you want some water?' 139 This instruction considerably improves the direction prior to 2004 to refrain from giving comforts to detainees, which was interpreted after the Battle of Danny Boy to permit the refusal of water. ${ }^{140}$ If captured persons are more seriously injured than British personnel, 'they get treated first'. They should receive 'equivalent' medical treatment for British personnel and CPERS: 'it is about parity.' Troops are reminded of their obligations to 'seek out ICRC' and give detainees the right to complain, ${ }^{141}$ to protect POW from insults and public curiosity, ${ }^{142}$ and of individual and command responsibility for IHL violations. ${ }^{143}$

\footnotetext{
${ }^{134}$ MATT 7 (2017) CPERS presentation and script 3.3.5.

135 ibid.

136 ibid., 3.3.11.

137 ibid.

${ }^{138}$ CPERS (2013) audio-visual materials.

139 ibid.

${ }^{140}$ Sir Thayne Forbes, 'Report of the Al-Sweady Public Inquiry', 17 December 2014; MATT 7 (2017) CPERS presentation and script, 3.3.9.

${ }^{141}$ MATT 7 (2013) CPERS.

${ }^{142} \mathrm{GC}$ III, art 13.

${ }^{143}$ MATT 7 (2013) CPERS.
} 
The 2015 Module on the Use of Force was partly classed 'Official Sensitive', including those on the content of the Card Alpha carried by soldiers. ${ }^{144}$ The unclassified sections explain 'offensive force' (governed by LOAC and ROE) and force in 'self-defence' (a soldier can open fire if he has an 'honest belief' that there is an 'imminent threat' to human life, ${ }^{145}$ but 'once the threat stops, you must stop'). ${ }^{146}$ In the 2017 instructors' script (which shows no particular classification), the legal basis for 'self-defence' is specified as domestic criminal law: ${ }^{147}$ Self-defence 'will apply in every operation', implying uncritically that there is no tension between domestic criminal law and IHL. ${ }^{148}$ Reflective teaching and judgement training is evident: soldiers and officers are asked how they would judge an 'imminent threat' (justifying self-defence) in a given hypothetical, and whether a particular weapon used in a film clip was a 'proportionate and necessary use of force'. ${ }^{149}$ Blending domestic law proportionality and necessity with IHL standards might cause confusion, which the instructors' script later attempts to avoid. ${ }^{150}$ The Card Alpha requires that soldiers use 'no more force than is absolutely necessary' and use firearms 'only as a last resort', reflecting IHRL. ${ }^{151}$ Soldiers and officers are reminded that LOAC applies to their use of offensive force whenever there is an armed conflict, guided by ROE. Soldiers or officers are required to make a positive identification (PID) of a lawful target, and potentially to undertake a collateral damage assessment (CDE) reflecting IHL proportionality and precautions. The $\mathrm{CDE}$ is influenced by the Targeting Directive and applicable ROE. Soldiers are reminded that the acceptable level of civilian casualties or damage to civilian objects in any given operation may be set at zero, so 'you would have to be satisfied that you do not expect any civilian casualties' from the planned attack, or it would not be authorised. A higher level of anticipated civilian casualties may be set, depending on operational and situational factors. ${ }^{152}$ Throughout the instructors' script, there are opportunities for reflective learning and to check understanding. This discursive approach represents an improvement on the 2015 MATT 7.

\footnotetext{
144 ibid., Operational Law, Policy Statement, 1.1, para 4.

${ }^{145}$ MATT 7 (2015) Use of Force, 3.2.4.

146 ibid., 3.2.6.

${ }^{147}$ MATT 7 (2017) Use of Force, 3.4.3.

148 ibid., 3.4.2.

149 ibid., 3.4.5, 3.4.7.

150 ibid., 3.4.31.

151 ibid., 3.4.8.

152 ibid., 3.4.30.
} 
Finally, a brief note on the IHL training to 'civilian authorities': an FOI request to the Foreign and Commonwealth Office (FCO) on how 'civilian authorities' will become 'fully acquainted' with Geneva law ${ }^{153}$ revealed a heavily-redacted set of minutes of the UK Inter-Departmental Committee on International Humanitarian Law. ${ }^{154}$ This shows tentative, minimal provision for IHL dissemination for 'civilian authorities'. As at 2001, IHL featured in the FCO's International Law Course, but the Civil Service College believed IHL too specialised for its introductory curriculum. The minutes reflect that individual government departments should receive 'something imaginative to point out ... that IHL was relevant to them', e.g. the potential for detention of prisoners of war within the UK involving the Home Office. ${ }^{155}$ Throughout 2018, the FCO Legal Directorate hosted the IHL Expert Lecture Series for government lawyers. ${ }^{156}$

\section{Critiques}

The British Army offers detailed training on IHL and the IHRL applicable to the use of force and the treatment of prisoners of war and other detainees. However, these are reactive reforms; the CPERS Module has a substantive bias towards the 'five techniques' prohibited since Ireland $v$ UK and re-emphasised by the Baha Mousa Public Inquiry. A proactive approach might have analysed the full range of conduct alleged to have been committed against detainees in British military custody and prominently forbidden from the earliest opportunity all forms of torture, inhuman or cruel treatment and outrages upon personal dignity. The latter are belatedly emphasised in the 2017 issue 9 of MATT 7. Page 3.3.4 specifies that outrages upon personal dignity include: 'humiliating and degrading treatment, all forms of sexual violence, sexual slavery, enforced prostitution, forced pregnancy, and forced sterilisation.' This list is an underinclusive account of outrages upon personal dignity, ${ }^{157}$ alluding instead to crimes against humanity; ${ }^{158}$ and it appears gendered. Troops might not realise that 'humiliating and degrading treatment' would also include sexually degrading strip searches of male fighters, and racist or Islamophobic taunts during such a search; or the

\footnotetext{
153 AP I, art 83(2).

154 UK National Committee on International Humanitarian Law, Minutes, 2001-2016, FOI 0051-17.

155 ibid., 16 October 2001, paras 5-7.

${ }^{156}$ UK National Committee on IHL and British Red Cross, 'United Kingdom Government: Voluntary Report on the Implementation of International Humanitarian Law at Domestic Level' (Foreign and Commonwealth Office 2019), 18-19.

${ }^{157}$ Outrages upon personal dignity are not limited to sexual crimes. They also include certain crimes against the dead: ICC Elements of Crimes, Art 8(2)(b)(xxi).

${ }^{158}$ Rome Statute of the International Criminal Court 1998, Art 7(1)(g); cf. Art 8(2)(b)(xxi), Art 8(2)(c)(ii).
} 
alleged rape of male detainees. In 2018, reiterated in 2019, the International Criminal Court Office of the Prosecutor (OTP) found a 'reasonable basis to believe' that a range of war crimes, including outrages upon personal dignity, rape and other forms of sexual violence were committed against those detained by the British Army in Iraq. ${ }^{159}$ The OTP's preliminary examination is ongoing at this writing.

Despite the clear prohibition of the 'five techniques' and on humiliating or degrading treatment, the CPERS training materials do not specify IHRL's prohibition on the intentional infliction of severe mental pain and suffering by public officials including the armed forces. This shows the reactive, selective nature of the training reforms, as this is a core element of the definition of torture in Article 1 of the CAT. The physical vulnerability of certain categories of detainees (defined by age, state of health or gender) is acknowledged, and 'corporal punishment' is listed alongside war crimes (it is prohibited by customary IHL and IHRL), ${ }^{160}$ but detainees' mental pain or suffering is not considered.

References to the necessity of restraint positions (as opposed to prohibited stress positions) may undermine the training's potential to prevent torture and other ill-treatment. In the 2017 instructors' script, there is no definition of a restraint position, despite the limitations on their use as detailed in section 3 above. The training materials suggest that stress positions themselves have a malleable, subjective definition: 'Whether a position is a stress position depends on the physical characteristics of the CPERS, and the type of position used. ${ }^{161}$ At best, this reflects the victimcentred definition of torture or inhuman or degrading treatment in the jurisprudence of the European Court of Human Rights; ${ }^{162}$ but at worst, it risks confusion in soldiers and officers being trained. When deployed, will they resort to institutional memory of the 'five techniques' instead of the international law prohibitions they might recall from operational law training?

Consistently with the UK's reservation to Articles 51-55 AP I, the 2017 training materials provide for the potential lawfulness of reprisals, yet this brief passage is a simplistic rendering of the UK's opinio juris on this point, compared to the text of the reservation. The training materials state that reprisals ('acts taken by one side to stop the other side committing war crimes': a partial

\footnotetext{
${ }^{159}$ International Criminal Court Office of the Prosecutor, 'Report on Preliminary Examination Activities' (2019) para 163.

${ }^{160}$ MATT 7 (2017) CPERS, 3.3.11, 3.3.4; ICRC Customary IHL Study, Rule 91 (applicable in IAC and NIAC).

${ }^{161}$ MATT 7 (2017) CPERS, 3.3.5.

${ }^{162}$ Ireland v UK (1978) 2 EHRR 25, paras 162, 167.
} 
colloquial definition which does not clarify that these 'acts' are themselves IHL violations) 'are not allowed unless they are authorised by the highest levels of the UK government' ${ }^{163}$ From one perspective, this is valuable, as it might prevent soldiers and officers engaging in tit-for-tat reprisals or IHL violations committed for revenge or perceived punishment. Yet from another perspective, it implies that IHL's normativity is politically flexible: that the 'highest levels of the UK government' can determine what is lawful or unlawful under international law. It also omits the procedural, substantive and temporal parameters of the UK's reservation: which expresses an 'entitle[ment] to take measures otherwise prohibited' by Articles 51-55 AP I only if an adverse party 'makes serious and deliberate attacks' in violation of any of those Articles, and then for the sole purpose and only to the extent necessary to prevent the adverse party from continuing such violations. Any UK reprisals would require not only 'a decision taken at the highest level of government' but also prior 'formal warning to the adverse party requiring cessation of those violations' which the adverse party then disregards; would 'not be disproportionate' in relation to the adverse party's violations, would not themselves violate the Geneva Conventions 1949 (as opposed to Articles 51-55 AP I), 'nor will such measures be continued after' the adverse party's violations had ceased; and would be communicated to the relevant Protecting Power. ${ }^{164}$ While soldiers and officers undergoing initial or continuation training would not need this level of procedural detail, the text on reprisals fails to define their applicability, general unlawfulness, and the scope of UK opinio juris on this point, which is arguably against the object and purpose of AP I, and fails to represent a consensus against the lawfulness of belligerent reprisals in IHL. ${ }^{165}$

Given the complexity of the training materials, soldiers' and officers' norm-by-norm understanding should be tracked and compared by training site, to ensure that there are no patterns of confusion or a failure to retain relevant prohibitions. Instead, each Training Delivery Authority uses the Operational Deployability Record (ODR) to record soldiers' and officers' MATT 7 attendance, completion and test results. ${ }^{166}$ Training sites give annual reports on the training conducted to the Director of Operational Law at ALS, for the purposes of internal evaluation. This is supplemented by an external evaluation, using the 'Army SMART Evaluation Policy'. ${ }^{167}$ The

\footnotetext{
${ }^{163}$ MATT 7 (2017) 3.3.4.

${ }^{164}$ UK, Reservation/Declaration (m) to API, 2 July 2002, available at the ICRC Treaty Database (n 35).

${ }^{165}$ For a nuanced study, see: Bryan Peeler, The Persistence of Reciprocity in International Humanitarian Law (Cambridge University Press 2019).

166 OpLaw TD, para 19.

167 ibid., para 20, note 22 .
} 
ODR's testing and training records will not yield data on the effectiveness of military instruction for each category of LOAC norm. These will be thin data only; a human resources approach to IHL training. Such an approach may help resolve the Systemic Issue flagged by the Systemic Issues Working Group that some individuals might miss the relevant training, ${ }^{168}$ but it will not test how well soldiers and officers retain and understand their training.

Training reforms have been presented as one reason to close criminal investigations into alleged war crimes. The MOD's Systemic Issues Working Group applies an unpersuasive distinction between 'deliberate acts' in violation of international law which are to be prosecuted by the Service Justice system; and 'systemic issues' including 'gaps in doctrine, policy and training'. ${ }^{169}$ The morally neutral term 'gaps' implies unintentional omissions, blameless violations, and easy bureaucratic solutions. In February 2017, the Defence Subcommittee asserted that all violations of international law in Iraq and Afghanistan had been caused by deficient training, that those deficiencies were now remedied by the much more comprehensive IHL training that is now in place; and that therefore, no prosecutions should take place. ${ }^{170}$ This narrative forces IHL training to do greater explanatory and exculpatory work than it can. It ignores the causal role of deliberate, knowing violations of IHL, ${ }^{171}$ of unlawful orders in violations of international law, of unwillingness to report torture and inhuman treatment, and of other failures of the command responsibility to prevent and repress grave breaches of the Four Geneva Conventions and AP I. The Baha Mousa Public Inquiry's emphasis on deficient IHL training might have led unintentionally to this false dichotomy, in which training reforms were presented as an easy bureaucratic solution, while the MOD set targets for the closure of criminal investigations by the Iraq Historic Allegations Team (2010-2017) and its successor the Service Police Legacy Investigations (SPLI), ${ }^{172}$ and Ministerial statements repeatedly asserted that allegations of war crimes were groundless. ${ }^{173}$ The IHL training obligation is coexistent with and does not replace the various obligations to investigate or to prosecute or extradite those suspected of being responsible for violations of international law in armed conflict.

\footnotetext{
168 SIWG, July 2015, Issue 52.

${ }^{169}$ Systemic Issues Working Group, reports 2014-2018 inclusive.

170 'Who Guards the Guardians? MoD Support for Former and Serving Personnel' (Defence Select Committee 2017).

${ }^{171} R$ v Alexander Wayne Blackman (2017) EWCA 190;

${ }^{172}$ Ministry of Defence News, 'IHAT to Close at the End of June' 5 April 2017.

${ }^{173}$ HC 1 March 2010, col 93W; 'Discredited Iraq War Probe to Be Shut down' Sky News (10 February 2017).
} 


\section{Conclusion}

Implementation of the IHL training obligation was delayed in the UK, despite official assertions; while officials denied IHL's applicability to colonial warfare, resisted the development of the law of NIAC, and sought to maintain the legitimacy of the nuclear deterrent. despite official assertions that it was taking place. Absent or perfunctory IHL training correlated with recurrent patterns of IHL violations, especially those against detainees in British military custody. These patterns of conduct suggest an institutional memory of torture and other ill-treatment which persisted from the 1950s to the 2000s. Following the death of Iraqi civilian Baha Mousa in British military custody in 2003, there were gradual changes to training from 2004-2011, and more comprehensive improvements from 2012-2017. Training materials for soldiers and officers are now ambitious in their coverage of IHL norms, and implement the 71 recommendations in the Baha Mousa Public Inquiry Report which the Ministry of Defence accepted. The CPERS Handling Drill, and audio-visual materials on the lawful treatment of detainees show an institutional commitment to prevent future ill-treatment through IHL training.

However, these are reactive reforms. A proactive approach might have analysed the full range of alleged war crimes committed against detainees in British military custody, and therefore prominently prohibited humiliating or degrading treatment of a sexual nature, and the international infliction of severe mental pain and suffering (part of the definition of torture in CAT Article 1). Norm-by-norm evaluation of soldiers' understanding would be helpful, in contrast to the simple pass/fail MATT 7 data available in the Operational Deployability Record. Such evaluation would also enable a critical assessment of MATT 7 materials on restraint positions, and the simplistic text on reprisals. Finally, government rhetoric has invoked reformed IHL training as a pretext to close criminal investigations into past violations. Reforms to training are offered as an assumed panacea for IHL violations, while accountability for violations is repeatedly and vocally resisted. As a result, IHL training is forced to do greater explanatory and exculpatory work than it can, to the detriment of coexistent investigatory obligations. 